RAUDHAH Proud To be Professional JurnalTarbiyah Islamiyah

Volume 5 Nomor 1 edisi Juni 2020

P-ISSN : 2541:3686

\title{
PESANTREN RAUDHATUL ULUM DALAM PENGEMBANGAN SUMBER DAYA MANUSIA
}

\author{
Candra Kirana \\ STIT Raudhatul Ulum Sakatiga \\ Email: candrakirana@stit-ru.ac.id
}

\begin{abstract}
This study aims to determine the concept or program of human resource development at Raudhatul Ulum Islamic Boarding School. The method in this research emphasizes the type of research file, while this qualitative approach is carried out as a research procedure that produces descriptive data in the form of written or oral words from people and the behavior observed by the author through observation, interviews and documentation regarding the development of Human Resources at Raudhatul Ulum Islamic Boarding School through the concept or program of the Directorate of HRD (Human Resources Development) of Raudhatul Ulum Islamic Boarding School. From the research results it is known that the Raudhatul Ulum Islamic Boarding School through Asdir Division (Human Resources Development) has a concept or program that is arranged systematically and planned Making a schedule of ongoing coaching with the qualifications of participants of educators, non-educators, students. Furthermore, monitoring to the evaluation stage of the program being run. The implementation process of Raudhatul Ulum Islamic Boarding School in developing Human Resources went quite well, most of the activities carried out went as planned by the pesantren. Based on the changes in the behavior of the Raudhatul Ulum Islamic Boarding School human resources after participating in a number of coaching activities and the rules applied by the HRD (Human Resources Development) the better, most of them showed good commitment to the pesantren, were able to work with sincerity and complete, have insight about Islam after participating in several activities and coaching.
\end{abstract}

Keywords, Pondok Pesantren Raudhatul Ulum 


\section{Pendahuluan}

Dalam perspektif Islam, pendidikan telah memainkan peran penting dalam upaya melahirkan manusia yang handal dan dapat menjawab tantangan zaman. Pendidikan Islam mempunyai peranan penting dalam peningkatan kualitas sumber daya manusia. Sesuai dengan cirinya sebagai pendidikan agama, secara ideal berfungsi dalam penyiapan SDM yang berkualitas tinggi, baik dalam penguasaan terhadap ilmu pengetahuan dan teknologi maupun hal karakter, sikap moral, dan penghayatan serta pengamalan ajaran agama. Secara singkat, pendidikan Islam yang ideal berfungsi membina dan menyiapkan anak didik yang berilmu, berteknologi, berketrampilan tinggi serta beriman beramal sholeh.

Tugas pokok pondok pesantren pada esensinya adalah mewujudkan manusia dan masyarakat Islam Indonesia yang beriman dan bertaqwa kepada Allah SWT. Keunggulan SDM yang diinginkan pondok pesantren adalah terwujudnya generasi muda yang berkualitas yang tidak hanya pada aspek kognitif, afektif dan psikomotorik, dengan lebih mengorientasikan peningkatan kualitas santrinya kearah penguasaan ilmu pengetahuan dan teknologi dengan dilandaskan pada nilai-nilai luhur ajaran Islam.

Pendidikan pesantren berupaya melahirkan Sumber Daya Manusia (SDM) yang memiliki kepribadian yang berakhlak mulia, bermanfaat bagi masyarakat, sebagai pelayan masyarakat, mandiri, bebas dan teguh dalam kepribadian, menyebarkan agama atau menegakan agama Islam dan kejayaan umat Islam di tengah-tengah masyarakat ('izzul Islam wal muslimin). Paling tidak ada beberapa profesi yang diperankan oleh alumni pesantren, yaitu; pertama, mu'allim (pengajar). Kedua, Murrabi (pembimbing spiritual), dan ketiga, mujaddid (pembaharu). ${ }^{1}$

Selaras dengan pernyataan di atas bahwa pesantren merupakan lembaga pendidikan yang paling tepat dalam upaya membangun Sumber Daya Manusia, maka dalam pembelajaran yang dilaksanakan di Pondok Pesantren Raudhatul Ulum Sakatiga Indralaya Ogan Ilir tidak lepas dari usahanya dalam membangun Sumber Daya Manusia. Tujuan dari

${ }^{1}$ Ummu Yasmin, Materi Tarbiyah, (Solo: Medi Insani, 2004), hlm. 18 
lembaga pendidikan mendambakan profil lulusannya agar memiliki kompetensi dasar yang dituangkan dalam 10 jati diri Sumber Daya Insani yang dalam hal ini disebut Sumber Daya Manusia Pondok Pesantren Raudhatul Ulum.

Secara umum pesantren masih menghadapi kendala yang serius menyangkut pengembangan dan pemberdayaan Sumber Daya Manusia khususnya pada bidang HRD, salah satunya dalam pola perekrutan tenaga pendidik baru dalam memenuhi kebutuhan pengajar yang ada disetiap madrasah, penempatan asrama bagi mereka yang belum berkeluarga sehingga harus bersedia tinggal di dalam pondok pesantren mengikuti segala bentuk aturan yang diterapkan. Membantu Mudir dalam upaya membina para santri. Hal seperti ini bukanlah persoalan yang mudah bagi mereka untuk beradaptasi terutama bagi mereka yang bukan lulusan pesantren.

Perlunya pembinaan khusus terhadap SDM yang baru ataupun lama secara berkesinambungan dan terus menerus. Bekal pembinaan awal terhadap pengenalan tentang kepesantrenan sepertinya tidak cukup, ini terlihat masih ada sebagian dari mereka yang masih melakukan pelanggaran semisal memutus hubungan kontrak kerja sebelum berakhir masa perjanjiannya, tidak hadir dalam kegiatan mudzakarah, halaqah hingga malas jika ada kegiatan kerja bakti di lingkungan pesantren.

Permasalahan akan berbeda lagi dalam upaya pesantren mengembangkan karyawannya. Seyogyanya tugas mereka berbeda karena pada umumnya mereka tidak terlibat langsung dalam upaya pembinaan para santri. Sebagian besar dari mereka bertugas pengelolaan dan pemeliharaan sarana dan prasarana pesantren. Kenyataannya mereka tetap dituntut untuk belajar tentang ilmu keislaman. Bidang HRD yang bergerak pada pemberdayaan Sumber Daya Manusia telah menyiapkan jadwal khusus pembinaan bagi mereka, namun berdasarkan hasil observasi awal penulis menemukan masih kurangnya minat mereka dalam belajar hal ini terlihat masih sedikit yang hadir. ${ }^{2}$

Dari uraian di atas maka peneliti tertarik untuk mengadakan penelitian dan mengkaji lebih mendalam bagaimana konsep Pesantren Raudhatul Ulum dan implementasinya dalam upaya mengembangkan Sumber Daya Manusia. Mengacu pada hal itu, peneliti melakukan penelitian ini dan membahasnya dalam bentuk tesis yang berjudul "Peran Pesantren Raudhatul Ulum Dalam Membangun Sumber Daya Manusia". Adapun yang melatarbelakangi penulis memilih Pesantren Raudhatul

2 Observasi awal yang dilaksanakan pada hari Rabu 4 Desember 2019 
Ulum Sakatiga pertama penulis belum menemukan peneliti terdahulu yang membahas tentang pengembangan Sumber Daya Manusia di Pondok Pesantren Raudhatul Ulum, selanjutnya Pondok Pesantren Raudhatul Ulum telah memiliki jenjang pendidikan mulai dari Taman Kanak-Kanak hingga Perguruan Tinggi serta di dukung oleh para Pendidik dan tenaga kependidikan yang memiliki latar belakang pendidikan serta lingkungan yang berbeda-beda.

\section{Metodelogi}

Jenis penelitian dalam kajian ini dilihat dari tempat penelitian dilakukan yaitu perpustakaan. Adapun penelitian ini yang berupa penelitian pustaka, maka dalam proses penghimpunan datanya, maka penulis menghimpun data berupa informasi melalui literatur-literatur yang penulis peroleh di perpustakaan berupa buku- buku ataupun artikelartikel yang penulis gunakan dalam mengkaji pengertian-pengertian, dan aspek-aspek pendidikan Islam.

\section{Kajian Pustaka}

\section{Pengertian Pondok Pesantren}

Zamakhsyari Dhofier dalam pandangannya mengenai pesantren merupakan suatu lembaga pendidikan tradisional, dimana para siswanya semua tinggal bersama dan belajar dibawah bimbingan guru yang lebih dikenal dengan sebutan kyai dan mempunyai asrama untuk tempat menginap santri. Santri tersebut berada dalam komplek yang juga menyediakan masjid untuk beribadah, ruang untuk belajar dan kegiatan keagamaan lainnya. Kompleks ini biasanya dikelilingi oleh tembok untuk dapat mengawasi keluar masuknya para santri sesuai dengan peraturan yang berlaku. ${ }^{3}$

Menurut Abdullah Syukri Zarkasyi dalam pandangannya mengenai pesantren merupakan suatu lembaga pendidikan Islam dengan sistem asrama dan di dalamnya ada yang bertindak sebagai pendidik dan sentral figurnya yaitu kyai, ajengan atau tuan guru, dan ada santri, asrama, ruang belajar dan masjid sebagai tempat sentralnya. ${ }^{4}$

Studi mengenai pondok pesantren telah banyak dilakukan kalangan sarjana muslim dan non muslim sebagai peneliti ilmu sosial dan

\footnotetext{
${ }^{3}$ Zamakhsyari Dhofier, Tradisi Pesantren, (Jakarta: LP3ES, 2015), hlm. 79

${ }^{4}$ Abdullah Syukri Zarkasyi, Pondok Pesantren Sebagai Alternatif Kelembagaan Pendidikan Untuk Program Pengembangan Studi Islam Asia Tenggara, (Surakarta: Universitas Muhammadiyah, 1990), hlm. 10.
} 
ilmu agama Islam. Sebut saja misalnya dari kalangan peneliti dalam negeri adalah Zamakhsyari Dhofier, Sudjoko Prasodjo, Mastuhu, Bahri Ghazali, Sukamto, Muhtarom H.M, dan peneliti luar negeri misalnya Manfred Ziemek, Karel A. Steenbrink, Martin van Bruinessen, dan peneliti-peneliti lainnya. ${ }^{5}$

\section{Telaah Tentang Manusia Sebagai Sumber Daya}

\section{a. Konsep Manusia}

Dalam al-Qur'an banyak ditemukan gambaran yang membicarakan tentang manusia dan makna filosofis dan penciptaannya. Manusia merupakan makhluk-Nya paling sempurna dan sebaik-baik ciptaan yang dilengkapi dengan akal pikiran. Dalam hal ini ibn 'Arabi sebagaimana yang dikutip oleh Ramayulis melukiskan hakikat manusia dengan mengatakan bahwa, "tidak ada makhluk Allah yang lebih bagus daripada manusia, yang memiliki daya hidup, mengetahui, berkehendak, berbicara, melihat, mendengar, berpikir dan memutuskan. Manusia adalah makhluk kosmis yang sangat penting, karena dilengkapi dengan semua pembawaan dan syarat-syarat yang diperlukan bagi mengemban tugas dan fungsinya sebagai makhluk Allah di muka bumi. ${ }^{6}$

Lewat al-Qur'an Allah memberikan rahasia-rahasia tentang manusia. Karenanya, kalau kita ingin tahu manusia lebih nyata, benar dan sungguh-sungguh, maka al-Qur'an memberikan gambaran tentang manusia sebagai berikut:

1). Menggunakan kata yang terdiri dari huruf Alif, Nun, dan Sin semacam Insan, ins, nas atau unas.

2). Menggunakan kata Basyar

3). Menggunakan kata Bani Adam, dan Zuriyat Adam ${ }^{7}$

b. Potensi Manusia

Al-Qur'an banyak membicara manusia, di antaranya yang dibahas adalah mengenai sifat-sifat dan potensinya. Al-qur'an banyak sekali mengungkap, memuja dan memuliakan manusia. Seperti pernyataan tentang diciptakannya dalam bentuk yang sebaik-baiknya.

${ }^{5}$ Mochtar Affandi, Kitab Kuning dan Tradisi Akademik Pesantren, (Jawa Barat: Pustaka Isfahan, 2009), hlm. 5.

${ }^{6}$ Ramayulis, Filsafat Pendidikan Islam, Analisis Filosofis Sistem Pendidikan Islam, (Jakarta: Radar Jaya Offset, 2015), hlm. 71

7 Abdul Rahman Shaleh, Muhbib Abdul Wahab, Psikologi Suatu Pengantar Dalam Perspektif Islam, (Jakarta: Prenada Media, 2004), hlm. 49 
Potensi manusia sebagaimana dijelaskan oleh al-Qur'an melalui kisah Adam dan Hawa. Bahwa sebelum kejadian Adam, Allah telah merencanakan agar manusia memikul tanggung jawab kekhalifahan di bumi, untuk maksud tersebut Allah memberikan akal dan rohani. Dengan akal dan rohani inilah Allah memberikan beberapa potensi kepada manusia, diantaranya;

1). Potensi untuk mengetahui nama-nama dan fungsi bendabenda alam.

2). Pengalaman hidup disurga, baik yang berhubungan dengan kecukupan dan kenikmatannya, maupun rayuan iblis dan akibat buruknya.

3). Petunjuk-petunjuk agama.

Potensi-potensi itulah yang diberikan Allah kepada manusia, yang menjadikanya berbeda dengan makhluk-makhluk lainnya.

\section{Pesantren Dalam Pengembangan Sumber Daya Manusia}

Pembangunan suatu bangsa memerlukan dua asset utama yaitu Sumber Daya Alam (natural resources), dan Sumber Daya Manusia (human resource). Kedua sumber daya tersebut sangat penting dalam menentukan keberhasilan suatu pembangunan. selanjutnya berbicara tentang kualitas Sumber Daya Manusia menyangkut pada dua aspek yaitu aspek fisik (kualitas fisik) dan aspek non fisik (kualitas non fisik) yang menyangkut kemampuan bekerja, berpikir, dan keterampilan-keterampilan lain.

Upaya meningkatkan kualitas Sumber Daya Manusia ini juga dapat diarahkan kepada kedua aspek tersebut. Untuk meningkatkan kualitas fisik dapat diupayakan melalui program-program kesehatan dan gizi. Sedangkan untuk meningkatkan kualitas atau kemampuan non fisik tersebut, maka upaya pendidikan dan pelatihan adalah yang paling diperlukan. Upaya inilah yang dimaksudkan dengan Pengembangan Sumber Daya Manusia. Dari uraian singkat tersebut dapat disimpulkan bahwa yang dimaksudkan dengan pengembangan Sumber Daya Manusia (Human Resource Development) secara makro adalah suatu proses peningkatan kualitas atau kemampuan manusia dalam rangka mencapai suatu tujuan pembangunan bangsa. ${ }^{8}$

Sebagai solusi alternatif, pondok pesantren yang telah dianggap mampu mewujudkan manusia seutuhnya dalam penguasaan ilmu

8 Soekidjo Notoatmodjo, Pengembangan Sumber Daya Manusia, (Jakarta: Rineka Cipta, 2017), hlm. 5 
pengetahuan dan teknologi. Hal ini, seiring dengan perkembangan pondok pesantren yang mulai membekali anak didik dengan berbagai kegiatan yang mengarah ketujuan pembentukan kepribadian tersebut. Sehingga, terhapuslah anggapan sebagian masyarakat yang menganggap bahwa pondok pesantren itu kuno dan terbelakang yang hanya mengurusi dan mempelajari urusan yang berkaitan dengan akhirat saja.

Pendidikan adalah suatu upaya untuk mengembangkan potensi manusia, sehingga mempunyai kemampuan untuk mengelola Sumber Daya Alam yang tersedia untuk mewujudkan kesejahteraan masyarakat. Kemampuan yang dikembangkan dari Sumber Daya Manusia ini mencakup berbagai aspek, utamanya aspek non fisik, yakni kemampuan berpikir, penalaran, intelektual, keterampilan, dan sebagainya. Untuk mengembangkan kemampuan seperti ini, dengan sendirinya diperlukan kemampuan menyerap informasi melalui berbagai cara, utamanya membaca dan menulis, lamanya mengenyam pendidikan formal dan sebagainya. ${ }^{9}$

Fitriyawati Indah, 2010, dari Magister Pascasarjana UIN Sunan Ampel Surabaya Jurusan Magister Pendidikan Islam, mengangkat judul tentang "Upaya Peningkatan Kualitas Sumber Daya Manusia Pondok Pesantren (Studi Kasus di Pondok Pesantren Tahsinul Akhlaq Bahrul Ulum Surabaya)". Penelitian ini untuk mengetahui secara khusus tentang upaya peningkatan kualitas Sumber Daya Manusia Pondok Pesantren Tahsinul Akhlak Bahrur Ulum Surabaya. Adapun tujuan dari penelitian ini adalah untuk mendeskripsikan upaya Pondok Pesantren Tahsinul Akhlak Bahrur Ulum Surabaya dalam meningkatkan kualitas Sumber Daya Manusia serta mengetahui masalah-masalah yang dihadapi pesantren Tahsinul Akhlak Bahrur Ulum Surabaya dalam meningkatkan Sumber Daya Manusia. ${ }^{10}$

Yusni Fauzi, 2017, Jurnal, Fakultas Pendidikan Islam dan Keguruan Universitas Garut "Peran Pesantren Dalam Upaya Pengembangan Manajemen Sumber Daya Manusia Entrepreneurship (Penelitian Kualitatif di Pondok Pesantren Al-Ittifaq Rancabali Bandung)", Tujuan penelitian ini adalah untuk mengetahui peran yang dilakukan Pesantren Al-Ittifaq Bandung dalam upaya pengembangan Manajemen Sumber Daya Manusia

\footnotetext{
${ }^{9}$ Soekidjo Notoatmodjo, Pengembangan...op.cit., hlm. 2

${ }_{10}$ Fitriyawati Indah. (2010). Upaya Peningkatan Kualitas Sumber Daya Manusia Pondok Pesantren (Studi Kasus di Pondok Pesantren Tahsinul Akhlaq Bahrul Ulum Surabaya)". Tesis pada MPI UIN Sunan Ampel Surabaya. Tersedia: https://www.digilib.uinsby.ac.id [24 Februari 2019].
} 
(MSDM) Entrepreneurship. Metode Penelitian yang digunakan adalah metode penelitian kualitatif, dengan teknik pengumpulan data observasi partisipan, wawancara mendalam, studi dokumentasi, studi kepustakaan dan triangulasi, dengan teknik sampling yang digunakan adalah purposive sampling dan snowball sampling. Teknik analisis data dengan melakukan data reduction, data display, dan clonclution drawing/verification. Berdasarkan hasil penelitian di lapangan, Pesantren Al-Ittifaq Bandung mampu memfungsikan perannya dalam upaya pengembangan Manajemen Sumber Daya Manusia (MSDM), yang berperan dalam pengembangan santri dan masyarakatnya dalam membangun jiwa entrepreneurship sesuai dengan potensi sumber daya alam yang berada di lingkungan pesantren. ${ }^{11}$

\section{Metode Penelitian}

Penelitian ini bertujuan untuk mengetahui konsep atau program pengembangan Sumber Daya Manusia di Pondok Pesantren Raudhatul Ulum Desa Sakatiga Kecamatan Indralaya Kabupaten Ogan Ilir. Metode dalam penelitian ini lebih menekankan pada jenis file research. Adapun pendekatan kualitatif ini dilakukan sebagai prosedur penelitian yang menghasilkan data deskripsi berupa kata-kata tertulis atau lisan dari orang-orang dan perilaku yang diamati. Adapun subjek penelitian meliputi SDM Pendidik, SDM Non Pendidik dan Santri Pondok Pesantren Raudhatul Ulum.

Teknik pengambilan data melalui observasi mengenai prilaku dan situasi sosial Sumber Daya Manusia Pondok Pesantren Raudhatul Ulum, wawancara kepada pihak HRD (Human Resources Development), dewan guru, karyawan pesantren dan santri mengenai konsep, pola pembinaan dan pengembangan SDM serta dokumentasi berupa absensi kehadiran di setiap kegiatan yang diselenggarakan Pondok Pesantren Raudhatul Ulum. Analisis data menggunakan teknik analisis yang dikemukakan oleh Miles dan Huberman dengan tahapan reduksi data, penyajian data serta penarikan kesimpulan (verivication). ${ }^{12}$ Hasil dari penelitian menunjukan implementasi Pondok Pesantren Raudhatul Ulum dalam mengembangkan Sumber Daya Manusia berjalan cukup baik, hampir sebagian besar kegiatan yang dilaksanakan berjalan sebagaimana yang di rencanakan pesantren.

11 Fauzi, Yusni. (2017). Peran Pesantren Dalam Upaya Pengembangan Manajemen Sumber Daya Manusia Entrepreneurship (Penelitian Kualitatif di Pondok Pesantren AlIttifaq Rancabali Bandung). 06, (01), 1-8.

${ }^{12}$ Sugiyono, Metodologi Penelitian Bisnis, (Bandung: Alfabeta, 2008), hlm. 430. 


\section{Pembahasan}

Pondok pesantren sebagai lembaga pendidikan agama Islam yang tumbuh dan berkembang telah mendapat pengakuan dari masyarakat sekitar. Keunikan sistem pondok pesantren dengan segala potensi yang dimilikinya menjadikan pondok pesantren tetap survive dan dianggap sebagai solusi alternatif bagi kehidupan masyarakat modern. Keberadaan pondok pesantren dalam era globalisasi ini, perkembangannya semakin menunjukkan eksistensinya sebagai lembaga pendidikan Islam yang berusaha menjawab segala tantangan perubahan zaman. Dengan melakukan pembenahan dan pembaharuan pada sistem yang dianutnya.

Dalam kaitannya dengan pengembangan Sumber Daya Manusia, pondok pesantren menjadi salah satu lembaga pendidikan Islam yang berada diluar jalur sekolah, mempunyai potensi dan kedudukan serta peran penting. Sifat kekeluargaan dan keakraban yang menjadi ciri khas pondok pesantren menjadikan masyarakat percaya bahwa pondok pesantren mampu mempertahankan nilai-nilai tradisi yang baik dan mengambil sesuatu yang baru yang lebih baik. Pada era globalisasi sudah menjadi keharusan adanya Sumber Daya Manusia yang berkualitas. Hal ini merupakan upaya pembangunan manusia seutuhnya. Dalam artian, manusia yang tidak hanya menguasai ilmu pengetahuan dan teknologi saja, tetapi landasan yang digunakannya adalah keimanan dan ketaqwaan. Adanya ilmu pengetahuan dan teknologi adalah merupakan cerminan dari kemantapan keimanan dan ketaqwaan seorang hamba kepada Allah SWT.

Pendidikan adalah suatu upaya untuk mengembangkan potensi manusia, sehingga mempunyai kemampuan untuk mengelola Sumber Daya Alam yang tersedia untuk mewujudkan kesejahteraan masyarakat. Kemampuan yang dikembangkan dari Sumber Daya Manusia ini mencakup berbagai aspek, utamanya aspek non fisik, yakni kemampuan berpikir, penalaran, intelektual, keterampilan, dan sebagainya. Untuk mengembangkan kemampuan seperti ini, dengan sendirinya diperlukan kemampuan menyerap informasi melalui berbagai cara, utamanya membaca dan menulis, lamanya mengenyam pendidikan formal dan sebagainya. ${ }^{13}$

${ }^{13}$ Soekidjo Notoatmodjo, Pengembangan Sumber Daya Manusia, (Jakarta: Rineka Cipta, 2017), hlm. 2 
Adapun konsep dan implementasi Pondok Pesantren Raudhatul dalam upaya Pengembangan Sumber Daya Manusianya sebagai berikut:

\section{Gambaran Konsep Pondok Pesantren Raudhatul Ulum Dalam} Pengembangan Sumber Daya Manusia.

Untuk mengembangkan dan memajukan pesantren maka Pondok Pesantren Raudhatul Ulum telah merumuskan kebijakan-kebijakan yang dituangkan dalam strategi berikut:

1. Peningkatan dan pengembangkan kualitas serta optimalisasi pemberdayaan Sumber Daya Insani (SDI).

2. Peningkatan dan pengendalian mutu pendidikan pesantren.

3. Peningkatan kepedulian dan dukungan keluarga besar pesantren, masyarakat, pemerintah dalam penyelenggaraan pendidikan.

4. Peningkatan sarana dan prasarana pendukung pendidikan.

5. Peningkatan sumber dana pesantren (Profil PPRU, 2018 hal. 42).

Pondok Pesantren Raudhatul Ulum memiliki Sumber Daya Manusia yang cukup banyak, berdasarkan data yang penulis dapat di bidang HRD (Human Resources Development) dengan rincian 123 putra dan 127 putri total keseluruhan 250 Sumber Daya Manusia di Pondok Pesantren Raudhatul Ulum serta dengan jumlah santri/wati pada tahun ajaran 2019/2020 berjumlah 2321. Adapun mekanisme yang diterapkan bidang HRD (Human Resources Development) dapat dilihat dari tabel berikut.

Tabel 1

Program Kerja Bidang HRD

Pondok Pesantren Raudhatul Ulum

\begin{tabular}{|c|l|l|}
\hline No & \multicolumn{1}{|c|}{ Program Kerja } & \multicolumn{1}{|c|}{ Petugas } \\
\hline 1. & Melakukan Rekrutmen dan Placement & Team HRD \\
\hline 2. & Mengadakan Pembekalan SDM Baru & Team HRD \\
\hline 3. & Menertibkan Administrasi HRD & Team HRD \\
\hline 4. & $\begin{array}{l}\text { Mengadakan Pembinaan Ruhiyah, } \\
\text { Fikriyah, Jasadiyah dan Pemberdayaan } \\
\text { SDM }\end{array}$ & Team HRD \\
\hline 5. & $\begin{array}{l}\text { Mengevaluasi dan Memantau Kegiatan } \\
\text { Pembinaan }\end{array}$ & Team HRD \\
\hline 6. & $\begin{array}{l}\text { Melaksanakan Reward dan Punishment } \\
\text { terhadap SDM }\end{array}$ & Team HRD \\
\hline 7. & Menyelenggarakan Rapat-Rapat & Team HRD \\
\hline
\end{tabular}




\begin{tabular}{|c|l|l|}
\hline & Pembinaan Bidang, Pengurus dan Guru & \\
\hline 8. & $\begin{array}{l}\text { Mengkoordinir Kegiatan Sosial SDM } \\
\text { PPRU }\end{array}$ & Team HRD \\
\hline 9. & Menerima Konseling SDM & Team HRD \\
\hline
\end{tabular}

Sumber: Dokumentasi Asdir Bidang HRD (Human Resources Development).

Dalam menjalankan program pembekalan dan pembinaan bagi Sumber Daya Manusia Pondok Pesantren Raudhatul Ulum dimulai dengan beberapa tahapan yaitu:

a. Melakukan Rekrutmen dan Placement.

b. Mengadakan Pembekalan SDM Baru.

c. Mengadakan kegiatan pembinaan dan pemberdayaan SDM

d. Mengevaluasi dan Memantau Kegiatan Pembinaan dan Pemberdayaan.

e. Melaksanakan reward dan punishment terhadap SDM

f. Menyelenggarakan rapat-rapat pembinaan bidang, pengurus dan guru.

g. Mengkoordinir kegiatan sosial SDM PPRU.

h. Menerima konseling SDM.

Adapun para santri yang terkosentrasi 24 jam berada dalam lingkungan kampus yang Islami, dibina dan diasuh dengan sistem pendidikan yang terpadu.

\section{Peran dan Implementasi Pesantren Dalam Mengembangkan Sumber Daya Manusia.}

a). Pengembangan Sumber Daya Manusia bagi pendidik Pondok Pesantren Raudhatul Ulum.

Penerapan perencanaan dan pengembangan SDM harus sejalan dengan perencanaan strategik perusahaan. Oleh karena itu pengembangannya harus memperhitungkan budaya perusahaan. Budaya perusahaan yang dimaksud adalah pola nilai moral dan perilaku yang dianut oleh perusahaan yang membedakan dengan perusahaan yang lain. Dengan demikian, penerapan program perencanaan dan pengembangan SDM menjadi efektif. ${ }^{14}$ Dalam hal ini perusahaan yang penulis maksud ialah Pondok Pesantren Raudhatul Ulum, konsep dan perencanaan pengembangan Sumber Daya Manusia disusun sedemikian rupa oleh bidang HRD dengan menyesuaikan aturan dan budaya Pondok Pesantren Raudhatul Ulum.

${ }^{14}$ A. Anwar Prabu Mangkunegara, Perencanaan dan Pengembangan Sumber Daya Manusia, Bandung: PT Refika Aditama, 2014), hlm. 31 
Pemberdayaan terhadap SDM Pendidik, terutama yang baru pihak HRD (Human Resources Development) sudah terbilang baik dalam menjalankan program pembekalan dan pembinaan bagi SDM pendidik Pondok Pesantren Raudhatul Ulum, dimulai dari melakukan Rekrutmen dan Placement hingga tahap reward dan punisment yang diberikan.

Mereka diberikan pembekalan dan pembinaan tentang kepesantrenan, pembekalan ini sangat penting sebagai media awal mereka mengenal tentang kepesantrenan terutama bagi SDM pendidik yang berlatar belakang bukan pesantren. Secara berkala mereka tetap diberikan pembinaan dan pemberdayaan sebagaimana progam yang dicanangkan pihak HRD.

Pada tahap selanjutnya pihak HRD (Human Resources Development) mengevaluasi serta memantau kegiatan pembinaan dan pemberdayaan yang telah dilaksanakan. Program tersebut di atas mendapat apresiasi yang positif di kalangan para dewan guru Pondok Pesantren Raudhatul Ulum Sakatiga salah satunya ustadz Ainul Wafa guru SMPIT Raudhatul Ulum, beliau mengungkapkan tentang pentingnya program ini dalam rangka untuk meningkatkan kuantitas dan kualitas kita sebagai manusia.

“Program Pembinaan di PPRU ini sangat luar biasa sebagai upaya untuk meningkatkan kualitas dan kuantitas SDMnya, seperti mudzakarah, riyadhoh, kerja bakti, halaqah tarbawiyah, makan bersama, halal bil halal, dll yang bisa semakin mensolidkan kerjakerja SDM serta terjaganya ukhuwah antar sesama SDM. Saya sangat merasakan betul manfaatnya, seperti setelah mengikuti mudzakarah dan halaqah tarbawiyah kita ini merasa belum ada apaapanya dibandingkan dengan yang lainnya, sehingga kita bisa terhindar dari sifat sombong dan harus tetap rendah hati, serta terus berusaha belajar dan belajar, sedangkan dalam riyadhoh dan kerja bakti juga kita diajarkan suasana kebersamaan dan kedisiplinan" 15

Hal ini senada dengan apa yang disampaikan oleh ustadzah Amaliyah yang merupakan seorang guru senior, mulai mengabdikan dirinya di Pondok Pesantren Raudhatul Ulum pada tahun 1993 pihak pesantren sudah banyak melakukan upaya dalam meningkatkan potensi

15 Ainul Wafa, Guru SMPIT Raudhatul Ulum, hasil wawancara mengenai program pembinaan SDM Pondok Pesantren Raudhatul Ulum, pada tanggal 15 Januari 2020. 
SDMnya melalui upaya dalam peningkatan taraf pendidikan dan pengadaan sarana prasarana.

"Alhamdulillah, sudah ada upaya pesantren dalam meningkatkan potensi para SDMnya, ini bisa kita lihat dari pengadaan sarana dan prasarana sebagai penunjang bagi kami untuk terus berusaha mengembangkan dan memperbaiki diri dan satu lagi kami diberikan fasilitas untuk menyelesaikan pendidikan S1 di STITRU" 16

Melihat apa yang disampaikan oleh ustadzah Amaliyah mengindikasikan adanya upaya pesantren dalam meningkatkan pengembangan Sumber Daya Manusianya tidak hanya pada pengembangan potensi dan kualitas diri melainkan juga pada peningkatan taraf pendidikan dengan memfasilitasi mereka untuk menyelesaikan pendidikan S1 di Sekolah Tinggi Iilmu Tarbiyah Raudhatul Ulum.

Selanjutnya Sumber Daya Manusia Pondok Pesantren Raudhatul Ulum yang memiliki komitment terhadap pesantren, mereka tetap mendapat binaan secara berkesinambungan. Sebagai bentuk apresiasi mereka yang memiliki komitmen yang tinggi akan mendapat reward bahkan punisment sesuai dengan ketentuan pondok pesantren.

Lebih lanjut mengenai bentuk reward yang diberikan dalam setiap tahunnya Pondok Pesantren Raudhatul Ulum memberangkatkan umrah bagi SDM yang memiliki komitmen yang tinggi terhadap pesantren. Mekanisme penentuan peserta dan pemberangkatan tentunya dengan memperhatikan ketentuan-ketentuan dari pesantren.

b). Pengembangan Sumber Daya Manusia bagi karyawan non pendidik Pondok Pesantren Raudhatul Ulum.

Secara khusus penulis menyoroti jumlah SDM non pendidik yang secara kuantitas mereka cukup potensial untuk diberdayakan. Istilah pemberdayaan di sini adalah mereka sebagai SDM non pendidik pada diri mereka diharapkan tetap memiliki nilai-nilai keislaman. Pondok Pesantren Raudhatul Ulum sudah memberikan perhatian khusus kepada mereka dengan memberikan program pembinaan berupa mentoring atau halaqoh tarbawiyah yang dibimbing langsung oleh seorang ustadz.

Keefektivitasnya kegiatan ini memiliki peran penting dalam menumbuhkan jiwa dan nilai-nilai keislaman di dalam diri mereka. Adapun materi dan pokok bahasan yang dibahas dalam setiap pertemuan

16 Amaliyah, Guru Madrasah Aliyah Raudhatul Ulum, hasil wawancara mengenai program pembinaan SDM Pondok Pesantren Raudhatul Ulum, pada 16 Januari 2020. 
pembahasan fiqih taharah hingga keutamaan shalat sebagaimana yang disampaikan ustadz Kgs Abdul Gamal selaku Murabi menjelaskan:

"yang menjadi pembina tidak hanya saya saja, kami ada 4 orang yang dijadwalkan secara bergilir, terkadang yang mengisi $\mathrm{KH}$. Abdul Karim Umar, ustadz Basiruddin Rahmat atau ustadz Alman Faluty. Materi yang saya ajarkan mengenai fiqih taharah, jika ada yang perlu saya praktekan saya berikan contoh kepada mereka. Secara pribadi saya menaruh harapan setidaknya mereka bisa berwudhu dan shalat dengan benar, alhamdulillah ini terlihat dengan sebagian besar dari mereka mau shalat berjamaah dengan kita bahkan shalat shubuhnya" 17

c). Pengembangan Sumber Daya Manusia bagi Santri Pondok Pesantren Raudhatul Ulum.

Pendidikan di Pondok Pesantren Raudhatul Ulum memberikan perhatian yang besar pada pembinaan Bahasa Arab dan Inggris secara aktif dan intensif. Kedua bahasa tersebut, selain dijadikan bahasa pengantar sebagian besar mata pelajaran, juga dijadikan bahasa percakapan harian santri. Bahasa Arab dipandang amat penting, karena bahasa untuk memahami Al-Qur'an dan As-Sunnah di samping merupakan bahasa komunikasi dunia Islam, sedangkan Bahasa Inggris dianggap penting karena merupakan bahasa Ilmu Pengetahuan dan Teknologi (IPTEK) serta bahasa komunikasi internasional. Mengenai perkembangan bahasa para santri tentu menjadi perhatian bersama para pendidik Pondok Pesantren Raudhatul Ulum yang diharapkan para santri lulusan Pesantren Raudhatul Ulum memiliki dasar-dasar pengetahuan dan kemampuan berbahasa Arab dan Inggris, baik aktif maupun pasif. Untuk menunjang penguasaan kedua bahasa tersebut maka diadakan kegiatan ekstrakurikuler bahasa dengan penanggung jawab Asdir Bagian Bahasa.

Pondok pesantren memiliki peran dalam mengembangkan potensi santrinya, terutama dalam memperdalam pengetahuan keagamaan. Pada dasarnya pengetahuan terutama pengetahuan di bidang agama yang di dapat pada pendidikan di luar pondok pesantren sangat sedikit sehingga wawasan terhadap ilmu-ilmu agama Islam juga sangat rendah. Seperti yang dikemukan salah satu santri, ia mengatakan:

\footnotetext{
${ }^{17}$ Kgs. Abdul Gamal selaku murabbi, hasil wawancara mengenai upaya pengembangan dan pembinaan SDM non pendidik Pondok Pesantren Raudhatul Ulum, pada tanggal 22 Januari 2020.
} 
"Keinginan saya masuk ke pondok karena saya ingin mempelajari nilai-nilai keislaman".

Lebih lanjut ia mengemukakan:

"selain itu motivasi saya masuk pondok pesantren ingin belajar tentang ilmu agama, mampu berbahasa arab dengan baik karena di sini ada ustadz khusus bagian bahasanya, membaca Al-Qur'an dengan benar karena saya memiliki cita-cita membahagiakan orang tua saya jika nantinya saya bisa lulus kuliah ke Madinah" 18

Di samping diberi pelajaran yang bersifat akademik siswa di Pondok Pesantren juga diberi kesempatan untuk mengembangkan kemampuan softskill atau pengembangan diri. Pengembangan diri diarahkan untuk pengembangan karakter peserta didik yang ditujukan untuk mengatasi persoalan dirinya hingga lingkungan yang ada disekitarnya. Kegiatan pengembangan diri ini ada pada program ekstrakurikuler yang dikelola oleh pihak madrasah bekerjasama dengan bidang kesiswaan hingga Organisasi Pelajar Pondok Pesantren Raudhatul Ulum (OP3RU). Para santri mengikuti kegiatan di luar jam sekolah formal yang cukup padat dan beragam, kursus atau les untuk memperdalam mata pelajaran yang diuji dalam UAN, olahraga dan kesenian. Semua program kegiatan di atas menjadi media bagi para santri untuk mengembangkan diri dan potensi mereka.

d). Perkembangan Sumber Daya Manusia Pondok Pesantren Raudhatul Ulum.

Pengembangan Sumber Daya Manusia yang berdimensi fisik dan nonfisik lahir batin tidak berhasil dengan baik tanpa suatu perencanaan dan sasaran yang tepat. Dalam hal ini perencanaan yang dilakukan Asdir Bidang HRD Pondok Pesantren Raudhatul Ulum dalam upaya optimalisasi kemampuan manusia untuk menghasilkan karya fisik maupun pemikiran diartikan sebagai pembinaan Sumber Daya Manusia. Pemberdayaan dan pengembangan Sumber Daya Manusia yang dilakukan oleh Pondok Pesantren Raudhatul Ulum hakikatnya menginginkan mereka menjadi Sumber Daya Manusia yang unggul dan kompetitif, Sumber Daya Manusia yang sadar akan butuh iman, Islam dan akhlak sehingga mampu memberikan manfaat kepada yang lainnya.

Perkembangan Sumber Daya Manusia Pondok Pesantren Raudhatul Ulum khususnya para pendidik sebagai alumni pesantren

${ }^{18}$ Hasil wawancara dengan Jordy Maulana Agusani santri kelas 3 Madrasah Aliyah yang menjabat Ketua OP3RU masa khidmah 2019-2020, pada tanggal 14 Januari 2020. 
untuk kembali mengabdikan dirinya sebagai seorang pengajar masih belum signifikan, hal ini dapat dilihat dari data SDM baru Tahun Pelajaran 2019/2020 yang masuk ke Asdir bidang HRD (Human Resources Development) dari 9 profesi guru yang dibutuhkan hanya 2 yang merupakan alumni Pondok Pesantren Raudhatul Ulum.

Adapun bagi SDM pendidik yang berlatar belakang bukan pesantren sudah mulai terbiasa dengan kehidupan di pesantren, aktif dalam berbagai kegiatan seperti muzakarah, halaqah tarbawiyah, bakti sosial dengan tanpa ada rasa kecanggungan seperti biasanya. Sebagian besar dari mereka telah dipercayakan sebagai wali asrama ikut andil mengurusi anak-anak santri di luar jam belajar mereka, amanah ini menjadi tempat bagi mereka untuk terus bisa mengembangkan diri dari rasa tanggung jawab.

Perlu diketahui dalam pelaksanaan kegiatan halaqah tarbawiyah dan muzakarah bagi SDM pendidik memiliki dampak dalam perkembangan diri mereka, sebagaimana yang pernah disampaikan oleh ustadz Ainul Wafa dalam wawancara penulis tentang pengembangan SDM Pondok Pesantren Raudhatul Ulum. Kegiatan tersebut selain menjadi wadah untuk mengembangkan ilmu pengetahuan, secara tidak langsung mampu membentuk komitmen diri semisal disiplin, rasa tanggung jawab dan ikhlas mengorbankan waktu untuk tetap hadir dalam pelaksanaan kegiatan-kegiatan tersebut.

Selanjutnya pada taraf jenjang pendidikan SDM pendidik juga mengalami perkembangan yang signifikan. Mereka yang mengajar dan mengabdikan diri diberikan kesempatan berkuliah di STIT Raudhatul Ulum untuk menyelesaikan pendidikan S1nya.

Pada perkembangan SDM non pendidik berdasarkan pada pengamatan penulis sudah mampu melaksanakan shalat dengan baik, sangat aktif melaksanakan shalat berjama'ah di masjid bersama para santri dan dewan guru lainnya, tentu saja ini senada dengan apa yang diungkapan oleh ustadz Fadil mengenai perkembangan SDM Pondok Pesantren Raudhatul Ulum, meskipun pada aspek lain masih terdapat kekurangan semisal masih rendah minat mereka untuk ikut serta dalam kegiatan olahraga bersama pada Jum'at pagi.

Pada aspek para santri, perkembangan mereka dalam bentuk jumlah minat belajarnya di Pondok Pesantren Raudhatul Ulum dari tahun ke tahun dapat dikatakan stabil bahkan cendrung meningkat. Berkaitan dengan kemampuan berbahasa para santri belum mampu menunjukan hasil yang signifikan, santri terkadang masih berbahasa Indonesia dalam 
aktivitas sehari-harinya, yang artinya belum mampu memenuhi capaian target dari Asdir Bidang Bahasa itu sendiri, begitu juga dengan pengelolaan kelompok bahasa yang belum berjalan maksimal seperti yang wacanakan sebelumnya.

Organsasi pelajar (OP3RU) adalah santri senior kelas XII Madrasah Aliyah sepertinya masih terus mendapat bimbingan dan pengawasan oleh bagian kesiswaan, ada rasa malas dan jenuh menjadi persoalan utama dalam organisasi ini.

Mengenai kualitas membaca Al-Qur'an para santri terbilang cukup baik hal ini didukung oleh pihak pesantren dengan memfasilitasi mereka kegiatan tambahan berupa halagah tarbawiyah yang dilaksanakan pada setiap malam Rabu, prioritas utama murabbi pada kegiatan ini adalah mendengarkan serta membimbing secara langsung santri membaca Al-Qur'an. Selain itu pondok pesantren juga telah memfasilitasi para santri penghapal Al-Qur'an dengan mendirikan rumah Tah\}fizul Qur'an pada tahun 2015.

Dengan demikian, lembaga yang bertanggung jawab dalam pengembangan dan pemberdayaan Sumber Daya Manusia bukanlah suatu pekerjaan yang mudah, butuh sebuah perencanaan yang matang agar program yang diterapkan terarah sesuai dengan tujuan yang diinginkan. Selanjutnya jika terdapat kekurangan dari program yang dilaksanakan akan menjadi evaluasi pesantren agar segera diperbaiki dan menjadi acuan untuk kepengurusan Asdir yang selanjutnya. 


\section{Kesimpulan}

Setelah membahas berbagai uraian dan penjelasan hasil penelitian tentang Pengembangan Sumber Daya Manusia di Pondok Pesantren Raudhatul Ulum, maka penulis dapat menyimpulkan bahwa:

a) Pondok Pesantren Raudhatul Ulum memiliki konsep dan program yang variatif dalam membina dan mengembangkan potensi Sumber Daya Manusia. Pihak HRD (Human Resources Development) selaku Asdir yang membidangi bidang ini membuat Program Kerja tersusun secara sistematis dan terencana.

b) Proses implementasi Pondok Pesantren Raudhatul Ulum dalam mengembangkan Sumber Daya Manusia berjalan sebagaimana mestinya, sebagian besar kegiatan yang dilaksanakan berjalan sesuai yang yang direncanakan pesantren khususnya bagian Asdir Bidang HRD, misalnya halaqah tarbawiyah, tahsin, mudzakarah Rabu pagi dan Senin sore, hingga riyadhoh bersama setiap Jum'at pagi.

c) Perkembangan SDM Pondok Pesantren Raudhatul Ulum setelah mengikuti beberapa kegiatan pembinaan dan aturan yang diterapkan pihak HRD (Human Resources Development) semakin baik, sebagian besar dari mereka menunjukan komitmen yang baik terhadap pesantren, mampu bekerja dengan ikhlas dan dan tuntas, memiliki wawasan tentang keislaman setelah mengikuti beberapa kegiatan halaqah tarbawiyah, rajin ke masjid untuk melaksanakan shalat berjama'ah bagi SDM non pendidik. Adapun mengenai perkembangan bahasa santri dan Organisasi Pelajar (OP3RU) masih terus diupayakan agar keduanya mampu berjalan secara maksimal, baik itu dari Asdir Bagian Bahasa atau Asdir Bagian Kesiswaan. 


\section{DAFTAR PUSTAKA}

Abdul Rahman Shaleh, Muhbib Abdul Wahab. (2004). Psikologi Suatu Pengantar Dalam Perspektif Islam. Jakarta: Prenada Media.

Abdullah Syukri Zarkasyi. (1990). Pondok Pesantren Sebagai Alternatif Kelembagaan Pendidikan Untuk Program Pengembangan Studi Islam Asia Tenggara. Surakarta: Universitas Muhammadiyah.

A. Anwar Prabu Mangkunegara. (2014). Perencanaan dan Pengembangan Sumber Daya Manusia. Bandung: PT Refika Aditama.

Ainul Wafa, Guru SMPIT Raudhatul Ulum, hasil wawancara mengenai program pembinaan SDM Pondok Pesantren Raudhatul Ulum, pada tanggal 15 Januari 2020.

Amaliyah, Guru Madrasah Aliyah Raudhatul Ulum, hasil wawancara mengenai program pembinaan SDM Pondok Pesantren Raudhatul Ulum, pada 16 Januari 2020.

Fauzi, Yusni. (2017). Peran Pesantren Dalam Upaya Pengembangan Manajemen Sumber Daya Manusia Entrepreneurship (Penelitian Kualitatif di Pondok Pesantren Al-Ittifaq Rancabali Bandung). 06, (01), 1-8.

Fitriyawati Indah. (2010). Upaya Peningkatan Kualitas Sumber Daya Manusia Pondok Pesantren (Studi Kasus di Pondok Pesantren Tahsinul Akhlaq Bahrul Ulum Surabaya)". Tesis pada MPI UIN Sunan Ampel Surabaya. Tersedia: https://www.digilib.uinsby.ac.id [24 Februari 2019].

Hasil wawancara dengan Jordy Maulana Agusani santri kelas 3 Madrasah Aliyah yang menjabat Ketua OP3RU masa khidmah 2019-2020, pada tanggal 14 Januari 2020.

Kgs. Abdul Gamal selaku murabbi, hasil wawancara mengenai upaya pengembangan dan pembinaan SDM non pendidik Pondok Pesantren Raudhatul Ulum, pada tanggal 22 Januari 2020. 
Mochtar Affandi (2009). Kitab Kuning dan Tradisi Akademik Pesantren. Jawa Barat: Pustaka Isfahan.

Observasi awal yang dilaksanakan pada hari Rabu 4 Desember 2019

Ramayulis. (2015). Filsafat Pendidikan Islam, Analisis Filosofis Sistem Pendidikan Islam. Jakarta: Radar Jaya Offset.

Soekidjo Notoatmodjo (2017). Pengembangan Sumber Daya Manusia. Jakarta: Rineka Cipta.

Sugiyono. (2008). Metodologi Penelitian Bisnis. Bandung: Alfabeta.

Ummu Yasmin. (2004). Materi Tarbiyah, Solo: Medi Insani.

Zamakhsyari Dhofier. (2015). Tradisi Pesantren. Jakarta: LP3ES. 